Natalia Yampolskaya*

\title{
Buddhist Scriptures in 17th Century Mongolia: Eight Translations of the Aṣțasāhasrikā Prajñāpāramitā
}

\author{
DOI 10.1515/asia-2014-1004
}

Abstract: The article suggests an approach to studying Mongolian translations of Buddhist texts in the seventeenth century based on a hypothesis that emerged as a result of a comparative study of eight different Mongolian translations of the Aștasāhasrikā Prajñāpāramitā sūtra. The comparative analysis was carried out in the light of canon studies, with a special regard to the way Buddhist sacred scriptures (in particular, texts from the $b K a$ ' 'gyur) were handled in seventeenth century Mongolia. The evolution of the manifestations of canonicity in Mongolian Buddhist text culture is described as a shift in attitude towards Tibetan source texts.

Keywords: Ashtasahasrika Prajnaparamita, Buddhist scripture translation, Mongolian Kanjur, translation practice in Mongolia

\section{Introduction}

The Aștasāhasrik $\bar{a}^{1}$ has a special status in Mongolian culture: this sūtra ${ }^{2}$ from the Prajñāpa aramitā section of the $b \mathrm{Ka}^{\text {' 'gyur }}{ }^{3}$ is spread in Mongolia in multitudinous

1 Aștasāhasrikā Prajñāpāramitā is a Mahayana sūtra dated to the first century AD. The Sanskrit text was translated into English by Edward Conze and published under the title The Perfection of Wisdom in Eight Thousand Lines (Conze 1975). The Tibetan title of the sūtra is Shes rab kyi pha rol tu phyin pa brgyad stong pa; in Mongolian translations it is most often called Bilig-ün cinadu kijayar-a kürügsen naiman mingya-tu, and in the oral tradition - Jadamba, a phonetic borrowing of the Tibetan brgyad stong pa (Eight Thousand).

2 Foreign words and names are italicised and given in the transliteration/transcription of the language they come from. In order to avoid confusion that can come from the absence of a fixed spelling in Mongolian texts, Mongolian names of Sanskrit and Tibetan origin are given in Sanskrit and Tibetan transliteration (E.g. Thar pa Pandita, not Darba Bandita). In the cases when the original spelling could not be restored, the names are spelled as found in the Mongolian source. Tibetan transliteration is given according to the extended Wylie system; in

*Corresponding author: Natalia Yampolskaya, Institute of Oriental Manuscripts of the Russian Academy of Sciences - Department of Central Asian and South Asian Studies, Dvortsovaya Emb. 18, St. Petersburg 191186, Russian Federation. E-mail: nataliayampolskaya@yandex.ru 
copies, associated with numerous rituals, and revered as a powerful symbol. Today eight different Mongolian translations of the Aștasāhasrikā are known. All of them are translations from Tibetan dated to the seventeenth -early eighteenth centuries. It is remarkable that the sütra was translated eight times in a period of 100-120 years, and it is probable that there were other translations that are still to be found. The eight translations of the Aștasāhasrikā are chronologically dispersed in such a way that they reflect the development of translation practice in Mongolia throughout the seventeenth century. The beginning of this period is highlighted by the manuscript edition of the Mongolian $b K a$ ' 'gyur of 1629 (the earliest edition that has come down to us), while its end is marked by the creation of the Beijing blockprint $b K a$ ' 'gyur edition (1720). Thus the development of the canonisation process also resonated in the texts of the Mongolian translations of the Aștasāhasrikā.

A detailed account of the comparative study of the Mongolian translations of the Aștasāhasrikā Prajñāpāramitā is presented in my doctoral thesis Canonicity in Translation. ${ }^{4}$ The research was carried out in the context of canon studies, as an attempt to comment on the problematic phenomenon of the Mongolian $b K a$ ' 'gyur. Following the tendency to critically approach the term canon when applied to collections of sacred texts in different cultures, and in particular - to the $b \mathrm{Ka}$ ' 'gyur, ${ }^{5}$ the study deals with the problem of textual authority and the processes of canonisation, focusing on the manifestation of canonicity in translated texts.

My research involved a comparative analysis of the texts' structure, content and vocabulary. This paper discusses the results of the pivotal stage of research the analysis of translating techniques aimed at revealing the possible motives and purposes of translation. The central aim is to show how the study of the translators' styles and methods of work can help to reveal their understanding of canonicity and authority of scripture, as well as to describe the principles and forces that defined the process and the manner of translating sacred texts. The

proper names the root letter of the initial syllable is capitalised. Mongolian transcription is given in the Mostaert-Vladimirtsov system, but the letters $c$ and $j$ do not have diacritical signs. 3 In Tibet the name $b K a$ ' 'gyur (Tib. "Translation of the Word", often spelled Kanjur) is given to a collection of sacred texts that are believed to contain the authentic words of the Buddha. It is a large (circa 108 volumes) collection of Buddhist scriptures that were translated into Tibetan (mostly from Sanskrit) starting from the seventh century AD. The first Tibetan edition of the $b K a$ ' 'gyur is dated to the early fourteenth century, the earliest Mongolian edition known today was compiled in 1629 based on one of the Tibetan editions (it has not been established which edition that was). The history of the transmission of the Mongolian $b K a$ ' 'gyur is described in: Kollmar-Paulenz 2002; Alekseev/Turanskaya 2013.

4 Yampolskaya 2013.

5 Smith 1993; Skilling 1997. 
method of analysis is based on the premise that a translation privileges those aspects of a text that the translator deems important. ${ }^{6}$ Speculating on the translators' motives and purposes, the paper attempts to grasp the matter that was transferred from the source to the target text.

\section{The translations, the sources, and their chronology}

The eight Mongolian translations of the Aștasāhasrikā are listed below according to their assumed chronology (not all of them could be accurately dated), divided into groups of "earlier" and "later" ones. As I will explain below, a fragmentary comparison of the text structure of the eight translations revealed recurring patterns of structural concordance between them, showing rather clearly that the translations fall into two groups of five and three. It is remarkable that this structure-based division is also connected with the chronology of the translations: the group of five contains the earlier translations (early to mid seventeenth century), the group of three - the later ones (mid seventeenth to early eighteenth century). This suggests that the earlier and later translations were based on Tibetan sources that come from two different edition "branches", or "groups", and that one of these groups was spread in Mongolia earlier in the seventeenth century, while later (in the second half of the century) it was superseded by the other one.

\subsection{The five earlier translations}

\section{(1) The Three Translators’ Manuscript, 1599-1603}

The earliest Mongolian translation of the Aștasāhasrikā known today is a rather unusual one. According to its colophon, the sūtra was translated by three

6 This method comes from the functional theories in translation studies, in particular - the Skopos theory that interprets translation as a purposeful activity. See: Reiss/Vermeer 1984; Vermeer 2004. The specific method of applying this modern theory to medieval material with its specific cultural context (emphasising that translation strongly influenced the development of national languages and literatures) was suggested by the British scholar Lynne Long who argues that to understand the function of translation in medieval literature one can employ modern methodology instead of relying fully on studying historical context. This approach is invaluable in the cases when historical information one possesses is insufficient. It is based on combining the Skopos Theory and the Polysystems Theory, developed in the works of Itamar Even-Zohar. See: Long 2010; Even-Zohar 1990. 
masters, Diduyba dKa' bcu Bla ma, Durqar Omboo Sñagbo Baysi and Brasi Baysi, who divided the text between themselves, each working on his own part. ${ }^{7}$ The translation was commissioned by Buyan Dayun Secen Qayan (1593-1603), ${ }^{8}$ son of Tümen Jasaytu Qayan. The colophon mentions Dalai Bla ma IV, which allows to date the translation to the first years of the seventeenth century. Only one source containing this translation is known to exist: a two-volume manuscript preserved in the Royal Library, Copenhagen (TTMsVol1, TTMsVol2). ${ }^{9}$

(2) The Translation by Āryadeva, 1608

In $1608^{10}$ the Aștasāhasrikā sūtra was translated into Mongolian by Sandasiri Dai Guusi Āryadeva by the request of Buyan-tu Secen Dalai Qatun, the wife of the youngest son of a certain Naggadara Dayicing Noyan, and Secen Bodhisattva Bigiji, the wife of Phag mo sKyabs Tayiji. No information concerning the personalities of Sandasiri Dai Guusi Āryadeva or the sponsors of the translation has been found. This study is based on the text of the manuscript XT-7 from the collection of the museum of Damdinsuren (ADMs). ${ }^{11}$

(3) The translation by bSam gtan Sengge, the $1620 \mathrm{~s}$

In the 1620s the sūtra was translated by bSam gtan Sengge, a famous translator who was part of the redaction committee of the Mongolian $b K a$ ' 'gyur of 1628-1629. This translation of the Aștasāhasrikā was included into this manuscript bKa' 'gyur edition. Among the sponsors of this translation was Secen Cügükür Tayiji, a nephew of Altan Qayan who ruled in the Qaracin tribe in Southern Mongolia. The translation of the Aștasāhasrikā by bSam gtan Sengge is very well presented in library

7 From the colophon of TTMsVol2: [159r] diduyba kabcu lam-a-luy-a:: durqar omboo sñagbo baysi: brasi baysi: yurbayula ügüleldün salbilcan töbed-ün kelen-ece mongyol-un kelen-tür orciyulba:

8 Kämpfe 1983: 136 (N23).

9 Bawden/Heissig 1971: MONG. 481, MONG. 482.

10 The colophon mentions the earth-male-monkey year, which could also refer to 1668 , or any other corresponding year in the 60-year cycle. This year is also called the year three thousand seven hundred and sixty nine after the nirvāna of the Buddha. I have not succeeded in establishing which of the different traditions of dating the Buddha's life this corresponds to. The author of the catalogue of the Museum of Damdinsuren in Ulaanbaatar, where the manuscript is preserved, interprets the year as 1608 , but does not give an explanation (Bilguudey 1998: 450). A few details suggest that the translation comes from the early seventeenth century, including the minimal use of Galik signs and inaccurate spelling of foreign words. Besides that, the colophon contains praises to Altan Qayan and the Dalai Bla ma as the special protector of the Mongolian people, which is likely to refer to Dalai Bla ma IV - the greatgrandson of Altan qayan.

11 Bilguudey 1998: 450. 
collections all over the world. ${ }^{12}$ The main source for this study was the volume from the manuscript $b \mathrm{Ka}$ ' 'gyur from the collection of St. Petersburg State University Library (SSMs). ${ }^{13}$

(4) The translation by Paṇdita Darqan Bla ma

In the collection of IOM RAS there are two manuscripts that contain a translation of the Aștasāhasrikā ascribed to Pandita Darqan Bla ma. ${ }^{14}$ The translation was commissioned by Dayicing Noyan - possibly, the grand- or great-grandson of the Abadai Sayin Qayan of Qalq-a (1554-1588). The exact time of translation, as well as the identity of Pandita Darqan Bla ma, remain unknown. This study relied on the manuscript Q223 (PDLMs). ${ }^{15}$

(5) The translation by Altan Gerel Ubasi, mid seventeenth century

Altan Gerel Ubasi was a prominent translator, known to have lived and worked in Qalq- $a$ in the middle of the seventeenth century. ${ }^{16} \mathrm{He}$ translated the Aștasāhasrikā by the request of Dayicin Qung Tayiji and Cayan Dara Qatun. Today only a few manuscript copies of his translation are known and described. $^{17}$ In this study a manuscript from a private collection was used (AGMs). ${ }^{18}$

\subsection{The three later translations}

(6) The translation by Jay-a Pandita, mid seventeenth century

The celebrated Oirat Buddhist scholar Jay-a Pandita Nam mkha’i rGya mtsho (1599-1662) also translated the Aștasāhasrikā. A manuscript containing this translation can be found in the collection of IOM RAS under the pressmark Q1 (JPMs). ${ }^{19}$

12 Sazykin 2001: 2631-2636; Bawden/Heissig 1971: MONG. 497, 498, 500, pp. 213-215; Catalogue of Ancient Mongolian Books and Documents of China 1999: 00331-00337.

13 Kas'yanenko 1993: 543.

14 Sazykin 2001: 2641, 2642.

15 Sazykin 2001: 2641.

16 Damdinsuren 1987: 121.

17 Catalogue of Ancient Mongolian Books and Documents of China 1999: 00338; Bilguudey 1998: 452; Mongolian National Library, Ulan-Bator: pressmarks 13416/97 (vol. 1) and 13405/97 (vol. 2). 18209 ff. (measurements not available), calamus, double-layer paper, black and red ink, no illustrations.

19 Sazykin 2001: 2639. 
(7) The translation by Thar pa Pandita, 1678-1702

Another translation of the Aștasāhasrikā of Qalq-a origin was discovered in 2011 in a private collection in Khovsgol province, Mongolia. Its author was Thar pa Pandita bLo bzang bZod pa rGyal mtshan (1637-1702), ${ }^{20}$ who worked by the request of Üijeng Noyan and his spouse Udbala (presumably, the title refers to Ayusi Üijeng Noyan ${ }^{21}$ ). It can be assumed that Thar pa Pandita translated the sütra after 1678, when he came back to Mongolia having spent a number of years in Tibet. The unique manuscript is preserved in a private collection in Mongolia, and was only partly available for research (a digital copy of the colophons, and the last, $32^{\text {nd }}$ chapter of the sūtra, TPMs). ${ }^{22}$

(8) The Anonymous Translation, early eighteenth century

Finally, there is a Mongolian translation of the Aștasāhasrikā, the authorship of which has not been established. This translation was included in the blockprint edition of the Mongolian $b K a$ ' 'gyur (Beijing, 1720), ${ }^{23}$ and was possibly created particularly for this purpose. It was printed separately several times. ${ }^{24}$ None of the editions available today have a Mongolian translator's colophon. This study mainly relied on the text of the $b K a$ ' 'gyur volume (1720), reprinted in the Satapitaka series (A-Kangxi). ${ }^{25}$

\section{The translations compared}

The genuine Tibetan sources that were used by the Mongolian translators of the Aștasāhasrikā are not known. In the absence of the relevant sources, The Tibetan $b K a$ ' 'gyur edition of $s D e$ dge was chosen to be used as a conventional text source for comparative analysis. Being a later edition (1733), the text of $s D e$ dge could by no means be used by the Mongolian translators of the seventeenth century, and the comparative study did not implicate that the relations between this Tibetan text and the Mongolian sources were direct. ${ }^{26}$ However, this edition successfully served as a conventional model for comparative analysis.

20 Dashbadrakh 2004: 189-194.

21 Kämpfe 1983: 160 (N840).

$22318 \mathrm{ff}$. (size unknown), calamus, black and red ink, circa 34 lines a page.

23 Ligeti 1942: 766.

24 Sazykin 2001: 2637, 2638, 2640; Catalogue of Ancient Mongolian Books and Documents of China 1999: 00340-00342; Poppe et al. 1964: 15, 16.

25 Lokesh Chandra 1977.

26 The study of the eight Mongolian translations showed that most of them were based on different Tibetan sources, so it was not possible to find one Tibetan text that would be equally 
The comparative analysis was carried out on several levels: overall structure (division into chapters, sections, volumes), correspondence of content, vocabulary, and finally - translation techniques. Each level contributed to the overall picture, which turned out to be peculiarly integral.

A detailed comparative analysis of Chapters 30 and 32 of the sūtra ${ }^{27}$ clearly showed that the earlier and later translations were based on two different groups of Tibetan source texts. The colophons of two Mongolian translations suggest that these could even be different Tibetan translations of the sūtra. ${ }^{28}$ The later translations fully agree with the Tibetan text of $s D e$ dge, which means that they were based on closely related Tibetan editions of the sütra. The five earlier translations proved to be based on mutually related, but not identical Tibetan editions. They vary in a significant number of cases, dissimilarities are found on different levels of text (from chapter titles to the wording of sentences), and are of diverse character. Due to the absence of the relevant Tibetan source texts it is not always possible to distinguish between the variances that originated from Tibetan sources, and those that come from the translators' choice of technique. However, it can be safely said that the earlier translations demonstrate more cases of divergence of all kinds, including those based on inconsistency and misunderstanding in translation (most of these are found in the two earliest translations - the works of Âryadeva and the Three Translators), while the later translations are uniform in both the structure of the text, and the wording.

Vocabulary analysis (based on a selection of 132 terms) showed that the share of common lexicon in the Mongolian translations of the Aștasāhasrikā is

relevant to all of them. One can assume that the Anonymous translation was either based on the Beijing edition of the Tibetan $b K a$ ' 'gyur (1684-1692), or edited according to this edition (based on the fact that the Mongolian Beijing $b K a$ ' 'gyur of 1720 was modelled after this earlier Tibetan edition). However, the history of each particular text does not necessarily repeat that of the whole $b K a$ ' 'gyur collection. Furthermore, a fragmentary comparison of several other Tibetan editions of the sūtra (Urga, Co ne, lHa sa, sNar thang, sTog pho brang bris ma) did not reveal significant differences between them (a thorough study of Tibetan versions has not been carried out). Finally, the choice fell on the text from the sDe dge $b K a$ ' 'gyur - an edition of mixed lineage. No conclusions were made based solely on the similarities or differences between the Mongolian translations and this Tibetan version.

27 Chapter 32 (the last chapter of the Aștasāhasrikā) was the only chapter available in all the eight translations, including the one by Thar pa Pandita. The text of Chapter 30 was compared in seven translations only.

28 Today only one Tibetan translation of the Aștasāhasrikā is known to exist, ascribed to Śakyasena, Jñānasiddhi, and Dharmatāsīla (these names are mentioned in all the Tibetan colophons known today. See, for example, sDe dge, 286r). However, according to the colophons of the Mongolian translations by bSam gtan Sengge and Äryadeva, there was an earlier Tibetan translation created in the eighth century by Acarya Śāntarakșita and his disciples. 
almost as high as $50 \%$. No direct connection between the time of translation and the character of lexicon could be traced. For instance, the earliest translation, the Three Translators' manuscript, has a very distinct vocabulary, which is visibly close to those of the much later translations by Jay-a Pandita and Thar pa Pandita (these three translations bear a marked influence of the Tibetan tradition: calque-translating of Tibetan terms is extensively used, in the two later translations borrowings from Tibetan appear). The results of the analysis suggest that in what concerns the seventeenth-early eighteenth centuries vocabulary patterns depend on the translator's preferences, or the tradition he belonged to, but not on the specific time period.

In vocabulary analysis special attention was paid to comparing the translation by bSam gtan Sengge (included in the manuscript $b K a$ ' 'gyur, 1629) with the Anonymous one (blockprint $b \mathrm{Ka}$ ' 'gyur, 1720). It is generally assumed that canons set, or at least exemplify the model to be followed, ${ }^{29}$ and the comparative analysis was aimed at testing this preconception. The lexicon of these canonical translations did prove to consist for the most part of widely established terms. In the Anonymous translation not a single term was found to be different from the majority. Besides that, the two translations demonstrate a rather high degree of mutual similarity: 100 out of 132 terms are identical. In a number of cases the differences in the choice of terminology show the variants used in the Anonymous translation (A) as more precise, closer to the Tibetan equivalents than in bSam gtan Sengge (SS) (E.g. Tib. stong pa nyid - SS: qoyosun - A: qoyosun cinar; Tib. rnam par shes pa - SS: medeküi - A: teyin medeküi).

\section{The variation of translations}

Focusing on this period in the history of the Aștasāhasrika in Mongolia, the first question to ask is: why was one sūtra translated eight times in the course of $100-120$ years?

The reasons for undertaking a translation of a sūtra into the Mongolian language could involve a combination of motives: "scholarly" (based on the absence of a Mongolian translation of the text, or the inadequacy of the existing translations), devotional (based on the understanding of the translational act as a merit for the benefit of all living beings and the Teaching), and political (associated with glorifying certain sponsors as Buddhist monarchs, when texts become symbols of power).

The Mongolian colophons of the Asțasāhasrikā contain passages that legitimise the translation, and give it a special status. These include references to

29 Jones 2005: 1405-1407. 
ancient prophecies of the Buddha, ${ }^{30}$ or lineages that show the link between the translational act and the creation of the sütra by the Buddha, and highlight the text's authenticity by building a bridge between the foreign, historically remote reality of ancient India and the seventeenth century Mongolia. To follow is an example from the colophon of Pandita Darqan Bla ma (PDLMs):

\section{Mongolian transcription}

English translation

[235v] qutuy-tu naiman mingyan silüg- When sthavira Subhuti, and a great tü egün-i number of other bodhisattvas, qubilyan bey-e-tü sigemuni burqan-tur: Qormusta Indra, and other gods, quvaray-ud-un aqamad subuti terigüten Asked the nirmanakaya buddha asanggi bodisung-nar kiged: Sakyamuni

qormusta asrua terigüten olan tngri-ner For this noble Eight Thousand ślokas, öcigsen-tür::

örösiyejü qotola amitan-i nigüles-ün The Buddha, the saviour of the living joriyad: beings,

öber-ün altan aman-u qayaly-a negejü With a merciful and compassionate bür-ün: intention,

ürü jirüken metü bilig-ün cinadu kijayar- Opened the gate of his golden mouth, a kürügsen-ü cinar-i:

öber-iyen büged amitan- $u$ itegel burqan And preached the essence of the nomlaysan egün-i:: heart-like Prajñāpāramitā.

erketü vcirai qayan-u altan uruy:

Now the golden descendant of the mighty Vcirai Qayan,

erke [236r] dayicing noyan kiged: The powerful Dayicing Noyan,

eke bodisung/dalai dagin-a qatun qoyar: Together with the mother Bodisung Dalai Dagin-a Qatun,

edüge burqan- $u$ sasin kiged olan- $u$ tusa- Thinking about the Teaching of the yi sedkijü::

Buddha, and the benefit of numerous [living beings],

mongyol-iyar orciyul kemen duradcu: Ordered to translate [the sūtra] into jarliy boluysan-tur:

Mongolian...

Such accounts show that the significance assigned to the act of translation of a canonical text was so great, that it alone could be a sufficient reason for

30 For example, the colophon of bSam gtan Sengge starts with these words: "According to the prophecy given by the great Lion of Śakyas, which said: 'This Prajñāpāramitā will spread from the North in the Northern direction', now [it] has spread to Mongolia." (Mong. sakyalig-ud-un degedü arslan-u vivangirid öggügsen: ene bilig baramid: umar-aca umar-a jüg-tür delgeremüi kemen jarliy boluysan-iyar: edüge mongyol ulus-tur delgeregsen...). SSMs, 83r. 
translating the sūtra. The necessity of a translation did not need to be justified by the unavailability of this particular text in the Mongolian language, or by the inaccuracy of the other existing translations.

The seventeenth century was an age of extraordinary translational activity, characterised by a lack of a dominant line that would govern this activity, in other words, a lack of a dominant canonisation process. ${ }^{31}$ The manuscript $b \mathrm{Ka}$ ' 'gyur edition sponsored by Liydan Qayan in the years 1628-1629 had a localised impact on the literary process of the period. The copies were handwritten, and their number was naturally limited. Thus, although the symbolical and political significance of undertaking such a major step in spreading the Buddhist faith in the Mongolian lands cannot be underestimated, the edition of 1629 could hardly affect the literary process on a large scale, if only because of its limited accessibility.

However, the impossibility of producing multiple copies of the canonical collection was not the only possible reason for the continuing emergence of new translations. Keeping in mind the specific manifestation of canonicity in Buddhist cultures, the openness of canons ${ }^{32}$ and the constant work on re-editing the texts, it would not be out of place to surmise that there was no strong need for strict uniformity of scripture, but rather a striving for constant perfection of the means of rendering the Word of the Buddha. There could be no other example for the Mongolian translators to model their work after than the Tibetan texts, and the role of the Tibetan source text in the canonisation process appears to be crucial.

Very little is known about the methods of translators in seventeenth century Mongolia. ${ }^{33}$ Scarce references, or details that indirectly cast light on this subject show that there was much more to the matter than one is likely to infer from

31 Canonisation process is understood here as evolvement towards the creation of a fixed model, in this case - an authoritative, institutionally recognised collection of texts. At the same time a canonisation process involves the development of literary repertoire. The concept of repertoire is borrowed from the Polysystems theory suggested by Itamar Even-Zohar: it is the aggregate of rules that govern the production and consumption of a literary product - the most patent manifestation of canonicity. See Even-Zohar 1990: 17.

32 One specific, hard-set canonical collection of Buddhist texts is nowhere to be found. The substance of the Buddhist canon has changed in time and due to confessional variations, its content being so vast and varied that it would be impossible to define what kinds of texts are to be included into the Buddhist canon based on any criteria other than those applied by every particular school. The differences in defining the bounds of the Buddhist canons are grounded in the divergence of views on the essence of buddhavacana - the Word of the Buddha. The appropriateness of calling collections of Buddhist scriptures canons has been justly questioned. See: Lopez 1995; Skilling 1997.

33 A lot more is known about translating Buddhist texts in the eighteenth century. For example, a number of multilingual vocabularies are described by Alice Sárközi. See Sárközi 2010: 101-109. 
working with the text. A text could have multiple translators who worked simultaneously (as one finds out from the colophon of the Three Translators' manuscript). Translation could be performed orally, "sight-read" by the translator and taken down by a scribe (this method is ascribed to Jay-a Pandita). The colophon that accompanies the Aștasāhasrikā in the translation by Altan Gerel Ubasi contains the following remark:

\section{Mongolian transcription} asuru olan eke töbed bicig-üd-i neyilegülün tokiyalduyulju: ayalyu udqasi aljiyas boluyujai kemen ariyudqan tegüskejü: altan gerel ubasi bi ali medegsen-iyen cinege-ber asuru kiciyejü mongyol-un kelen-dür orciyülju orosiyulbai::

\section{English translation}

Having collated many Tibetan source manuscripts

And made corrections to avoid errors in sounds and meaning, I, Altan Gerel Ubasi, to the extent of my knowledge Translated into the Mongolian language with great effort.

In this case the translator claims to have used multiple source texts. The use of varied source texts is characteristic of literature systems that belong to the medieval type, ${ }^{34}$ and this detail shows that the Mongolian translators' understanding of fidelity to the source text was not a plain matter of closely following Tibetan: their work involved a critical process, at least on some stages, or in some traditions.

34 Here the Mongolian literary system of the seventeenth-eighteenth centuries is understood as a medieval literary system, based on the definitions developed in the works of Yu. Lotman and B. Riftin. In his work "Canonical Art as an Information Paradox" (Lotman 1992: 243-247) Lotman speaks about certain epochs in culture (the age of folklore, medieval and classical epochs) when the production of art was based on following the canon, or ritualised. The model of communicating information in a "ritualized" text is based on triggering a certain layer of information that is already known to the reader, on urging to recall a piece of information or a piece of text. The form of such texts is strictly structured, its elements repeating from text to text. A "canonical" text is not a carrier of information, but an "arouser" of knowledge, which makes the historical context and the functions of these texts highly important, while gathering information about these functions from the text itself is hardly possible. In his article "Typology and Interrelation of medieval literatures” (Riftin 1974) B. Riftin questions the appropriateness of transferring the historical periodisation on the history of the literatures of the East (Riftin 1974: 9), referring, inter alia, to "young" cultures, or nations, the language and literature of which was formed and developed in a peculiar tempo: the "early medieval" stage can be skipped quickly, and the stage typologically close to "ancient" can be followed by the creation of literature of the medieval type. The development of these literature systems depends on historical context, and is closely connected to religion. The core of these literatures consists of texts that have a strong (in particular, a religious and ritual) function (Riftin 1974: 13). 
Two of the eight translations were included into $b K a$ ' 'gyur editions: the translation by bSam gtan Sengge is part of the manuscript $b \mathrm{Ka}$ ' 'gyur of 1629, and the Anonymous translation can be found among the volumes of the Beijing $b \mathrm{Ka}$ ' 'gyur printed in 1720 . We do not know whether these translations were made especially to become part of the canonical editions, or they were created earlier and chosen to be included into the $b \mathrm{Ka}$ ' 'gyur as the most suitable ones.

The process of work on the manuscript $b K a$ ' 'gyur is largely a mystery: it is not clear whether there was an earlier Mongolian translation of the whole canonical collection, ${ }^{35}$ which texts were translated anew, and which were newly edited earlier translations, ${ }^{36}$ and finally - which Tibetan $b \mathrm{Ka}$ ' 'gyur edition it was based on. The circumstances of the creation of the blockprint $b K a$ ' 'gyur of 1720 are more lucid. It is known to be based on the Beijing edition of the Tibetan $b K a$ ' 'gyur (1684-1692). Besides that, sources claim that the manuscript edition of the Mongolian $b \mathrm{Ka}$ ' 'gyur was used in the process of its creation. ${ }^{37}$ These two facts suggest that the choice of text could be made in the following way: the text of the sūtra from the manuscript edition (bSam gtan Sengge) was checked against the Tibetan text from the Beijing $b \mathrm{Ka}$ ' 'gyur edition, but did not correspond to it, because the translation by bSam gtan Sengge was based on a significantly different Tibetan source text (as comparative analysis allows to establish). That is when the Anonymous translation could be chosen as the closest to the Tibetan text, or, possibly, created especially to be included in the canonical collection.

Provided it was so, was the text of bSam gtan Sengge rejected completely, or did the creators and editors of the Anonymous translation still rely on it? I mentioned above that the lexicons of the two canonical translations are very close. It is possible that the editors of the blockprint $b K a$ ' 'gyur followed the work of bSam gtan Sengge, introducing changes in those aspects of text (be that content or terminology) that did not meet their criteria of correspondence to the source text. All these assumptions build a neat picture in which the work of the creators of the Mongolian $b K a$ ' 'gyur of 1720 was guided primarily by the

35 According to the early seventeenth century Mongolian chronicle Erdeni Tunumal Neretü Sudur (Kollmar-Paulenz 2001), a translation of the $b \mathrm{Ka}$ ' 'gyur was carried out at the turn of the seventeenth century in South Mongolia under the patronage of Namudai Sečen Qayan and his wife Jönggen Qatun. However, no material evidence of the existence of this $b \mathrm{Ka}$ ' 'gyur edition has been discovered yet. See Kollmar-Paulenz 2002: 156-157.

36 Some colophons in the manuscript $b K a$ ' 'gyur were changed in order to pass earlier translations for the work of the redaction committee under the patronage of Liydan Qayan. See Kollmar-Paulenz 2002: 151; Heissig 1957: 71-87; Heissig 1962: 5-42; Vladimirtsov 2003: 113.

37 On the creation of the two editions of the Mongolian $b K a$ ' 'gyur see Heissig 1957: 71-87; Heissig 1962; Kas’yanenko 1993: 13-18; Tuyay-a 2008; Uspensky 1997: 113-114. 
principle of following the Tibetan model in every detail. However, only a study of a larger number of texts from the two Mongolian canonical collections can prove this hypothesis to be right or wrong, as a history of a single text does not necessarily reflect this process in its diversity.

It is not known, whether the Aștasāhasrikā was ever translated again after the emergence of the Anonymous translation. It appears plausible that this canonical edition of the $b K a$ ' 'gyur in the Mongolian language, executed by the order of the emperor Kangxi, printed in Beijing and spread in multiple copies, finally sealed the process of canonisation. Possibly, new translations of canonical texts into Mongolian were not called for, because for the most part religious practices were performed in the Tibetan language.

The emergence of a number of different translations of one sūtra in the seventeenth century reflects the phase that the Mongolian literary process was going through at that time - the forming of the repertoire. The repertoire of the translated Buddhist literature in Mongolia, that is, the aggregate of laws and elements that governed the production of these texts, was not yet shaped enough to limit the freedom of the translators in the methods of their work, or to fully control the origination of new texts or new translations. In other words, this variety of translations, allowed for by the absence of a single central force in the literary process, and even the absence of a single source text, and triggered by extra-textual motives of devotional and political nature, is the manifestation of the canonisation process in full play.

\section{Translation techniques}

These observations come to life when one takes a closer look at how the translators worked with the source texts. To point out the methods employed by the Mongolian translators of the Aștasāhasrikā one short fragment of text was chosen for analysis. $^{38}$ The goal was to demonstrate a detailed instance of how a piece of scripture is transferred from one language into another, with special attention to the reconstruction of the translators' possible motives. Although generalisations cannot be made based on a small fragment of text, the results show the tendency of the translation methods to change in the course of the seventeenth century.

38 The passage is a fragment of a dialogue between the Buddha's disciples Subhuti and Sariputra from Chapter 1, a topical dispute in the context of the sūtra. It contains several questions and replies, as well as standard clichés introducing the speakers. The vocabulary is limited, the sentences are concise and of simple structure. As Chapter 1 is not available in the translation by Thar pa Pandita, the analysis only included the other seven Mongolian translations of the Aștasāhasrikā. 
The analysis focused on how close the translators follow the wording of the Tibetan text, what liberties they take in rendering it, and whether the target text (i.e. the Mongolian translation) can convey the original meaning and function independently from the source text. Besides that, it was aimed at finding similarities in the styles of the Mongolian translators, as well as common mistakes in their interpretations of the original text.

As a result three principal kinds of translation techniques were distinguished:

\subsection{Verbatim translation (each sentence is translated word for word, the original syntax fully preserved)}

This technique is employed to the fullest in the translation by Jay- $a$ Pandita. Here the Tibetan word order (unnatural for the Mongolian language) is never altered, the elements of the original grammar (case endings, etc.) are left unchanged, despite their different functions in the grammar of the target language. Terms are translated with fixed equivalents that do not change depending on the context. The translation gives the impression of being mechanical, as if the translation of the words in a sentence was carried out sequentially, without a prior estimation of the overall meaning of the fragment. The word order of the original being fully preserved, the words in the Mongolian sentence form new, different grammatical and semantic structures. In the larger perspective the inner logic of the text is disrupted: its parts do not agree in meaning, and even repeated fragments are interpreted in substantially different ways depending on the adjacent structures. This technique of thorough copying of the source text produces a target text that cannot function without references to the original.

Numerous examples of these features can be found in the translation by Jaya Pandita (JP). In his interpretation of the following fragment the Tibetan phrase yang $\mathrm{Ci}^{39}$ merges with the word sems, which he treats as a verb (to think). As a result, the question is translated as starting with the phrase basa yayun sedkimuii ([yet] again, what [do you] think?), where basa (again) corresponds to the Tibetan yang, yayun (what) - to ci, and sedkimüi (a present tense form of the verb sedkikü - to think) - to sems:

39 The Tibetan yang ci is a calque-translation of the Sanskrit phrase kim punar: the interrogation particle kim became the Tibetan ci, and the adverb punar (again, moreover, however) turned into yang (same meaning). The original question in Sanskrit is the following: Sanskrit: kim punarāyuṣman subhūte asti taccittam yaccittamacittam. See: Digital Sanskrit Buddhist Canon, http://www.dsbcproject.org/node/4357 (29/10/2014). 
Tib.: tshe dang ldan pa rab 'byor yang ci sems gang sems med pa'i sems de yod dam (Venerable Subhuti, a thought which is no thought - does that thought exist?)

JP: nasu tegülder subuti-a basa yayun sedkimüi ali sedkil ügei-yin sedkil tere bui buyu: (Venerable Subhuti, [yet] again, what [do you] think: a thought of no thought - does it exist?)

In the following fragment the question is repeated:

Tib.: tshe dang ldan pa sh'a ri'i bu 'di skad du sems gang sems med pa'i sems de yod dam zhes smras pa'i khyod kyi brgal ba gang yin pa de ci rigs par 'gyur ram/(Venerable Sariputra, is what you have said - "A thought without thought - does that thought exist?" - an appropriate argument?)

However, in this case Jay-a Pandita translates the question in a different way:

JP: nasu tegülder šari-yin köbegün eyin kemekü sedkil: ali sedkil ügei-yin sedkil tere bui buyu: kemen ügüleküi cinu getülügsen ali mön tere yayu basa bolqu buyu:

The difference emerges from the changed framework of the question: in this case it is framed with markers of direct speech (Tib. 'di skad du ... zhes smras pa). Thus no confusion takes place, and the Tibetan word sems is translated into Mongolian as sedkil in all its three occurrences. Besides that, Jay-a Pandita fully preserves the Tibetan word order, which in some cases (Tib. sems gang, sems de) is impossible in Mongolian. To function as a phrase the words sedkil ali and sedkil tere need to be inverted - ali sedkil, tere sedkil. The word order chosen by Jay-a Pandita does not allow to translate the sentence from Mongolian without a reference to the Tibetan original. Finally, some terms are interpreted erroneously. In particular, the Tibetan word brgal ba can be interpreted as a form of two different verbs: the verb rgal ba (to cross, to go beyond), and the verb rgol ba (to oppose, to object, to disagree). The context of the sentence makes it rather clear that the latter variant is the correct interpretation of the form brgal ba. Yet, Jay-a Pandita chooses the word getülügsen - a form of the verb getülkü that corresponds in meaning to the Tibetan rgal ba (to cross). This choice shows that the translator did not assess the context and message of the sentence, and picked the first option on his list. As a result the Mongolian sentence is incoherent (for the same reason an English translation could not be made).

\subsection{Restructured verbatim translation (syntax and word order are changed to fit the rules of the target language)}

This technique is characterised by a high level of fidelity to the original, allowing minor changes in the structure of the sentence. These changes primarily concern word order and elements of grammar that are 'rejected' by the target 
language. The restructured verbatim translation technique dominates in the works of the Anonymous translator, Altan Gerel Ubasi, and bSam gtan Sengge.

The positions of words inside phrases can be altered. Most examples from the analysed fragment demonstrate a change in the position of noun modifiers from post-position in Tibetan to pre-position in Mongolian. Repositioning of words and phrases inside a sentence occurs less frequently. Elements, the function of which in the target language is unnecessary or dubious, can be omitted. New elements that do not have any particular equivalents in the Tibetan sentence can be added to its Mongolian version in order to sustain the grammatical structure. The terms are not always translated with the same Mongolian equivalents: their translation is based on the interpretation of their meaning.

The latter point is well illustrated by the following sentence, in which the Tibetan word nyid is repeated four times:

Tib: tshe dang ldan pa shA ri’i bu yang ci sems med pa nyid gang yin pa'i sems med pa nyid de la yod pa nyid dam med pa nyid yod pa'am dmigs par yang 'gyur ram/(Venerable Sariputra, [yet] again, wha[tever] is absence of thought, in this absence of thought is there, or can [one] even conceive, a being or an absence?)

According to the principles of verbatim translation, Jay-a Paṇita (JP) translates nyid as cinar in all the four cases it occurs in the sentence:

JP: nasu tegülder šari-yin köbegün-e basa yayun sedkimü ügei cinar ali bügesü sedkil-ün cinar ügei tegün-e bui cinar buyu: ügei cinar bui buyu: joriqui cu bolqu buyu kü: (Venerable Sariputra, [yet] again, what [do you] think: what[ever] is absence, in this absence of the entity of thought is there a being or an absence, or is it possible to even contemplate [that]?)

This interpretation is based on one of the functions of the word nyid - that of forming abstract nouns (E.g. Tib. stong pa nyid - emptiness; ngo bo nyid - nature, 'entity-ness'). In the Anonymous translation nyid is rendered as cinar in a number of other cases (Tib. stong pa nyid (emptiness) - Mong. qoyosun cinar, Tib. ngo bo nyid (essence) - Mong. mön cinar). However, in this particular fragment the Anonymous translator (A) interprets the function of this word in two different ways:

A: amin qabiy-a-tu šaribudari-a basa ker alimad mön kü sedkil ügei-yin mön kü sedkil ügei tegün-dür bui ba ügei bui buyu: basa joriydaqu bolumuyu uи (Venerable Sariputra, [yet] again, in this absence of the very thought of what[ever] is absence of the very thought, is there being and absence? Moreover, is it possible to contemplate [that]?)

In the first two cases it is translated as mön kü (that very, the very), based on another meaning of the word nyid. In the other two cases the word is omitted: possibly, the translator deemed it superfluous, considering that the Mongolian words bui and ügei are adequate to convey the meaning of being and absence. 
The following fragment from the translation by Altan Gerel Ubasi (AG) is a perfect example of the restructured verbatim translation technique:

Tib.: tshe dang ldan pa sh'a ri'i bu 'di skad du sems gang sems med pa'i sems de yod dam zhes smras pa'i khyod kyi brgal ba gang yin pa de ci rigs par 'gyur ram/(Venerable Sariputra, is what you have said - "A thought without thought - does that thought exist?" - an appropriate argument?

AG: amin qabiy-a-tu saribudari eyin kemen ali sedkil sedkil ügegü tere sedkil bui uu kemen ügüleküi cinu ali tere temeceküi yosutu bolququ yayun: (Venerable Sariputra, what you have said - "A thought without thought - does that thought exist?" - is that arguing appropriate?)

The word order is changed according to the rules of the Mongolian language (Tib. sems gang - Mong. ali sedkil; Tib. sems de - Mong. tere sedkil). The same principle is applied in the final part of the sentence. Here the words ali tere (corresponding to the Tib. gang yin pa de) are moved to the position before the word temecekui (arguing; corresponds to the Tib. brgal ba) according to their function as its attribute. Most probably, the pronoun cinu (your; corresponds to the Tib. khyod kyi) refers to the word ügüleküi (ügüleküi cinu - what you have said), while in the Tibetan version it forms a different word combination (khyod kyi brgal ba - your argument). Finally, in the phrase is [that] appropriate? the interrogative pronoun yayun (corresponding to the Tib. $\mathrm{ci}$ ) is moved to the very end of the sentence. This way none of the words of the original text are lost, but the fidelity to the original does not compromise the structure of the Mongolian sentence.

\subsection{Interpretational translation (the sentence is rephrased according to the translator's interpretation of the meaning)}

This method does not necessarily involve rendering of each word of the original. The source text being followed closely, the sentence can be restructured to reflect the translator's understanding. This technique is employed in the works of the Three Translators, Pandita Darqan Bla ma, Aryadeva, and partly in the translation by Altan Gerel Ubasi. It allows alterations in the exact wording of the sentence, as well as omission of words. New elements or words can be added to the sentence. However, as opposed to restructured verbatim translation, it is not done in order to fit the Mongolian grammar, but rather to fit the translator's interpretation.

For example, In the following sentence Aryadeva (AD) adds the word ügülegsen (said) to clarify the meaning: 
Tib.: tshe dang ldan pa rab 'byor de ni med do/(Venerable Subhuti, that is not [so].)

$\mathrm{AD}$ : amin qabiy-a-tu subuti-a ügülegsen tere ber ügei buyu: (Venerable Subhuti, that [which was] said is not [so])

The changes brought to the sentence by the translator do not necessarily change its meaning. Yet, the translator's interpretation does not always correspond to the original.

In the following example the Three Translators (TT) shorten the sentence significantly, bringing a slight change to the meaning:

Tib.: tshe dang ldan pa rab 'byor yang ci sems gang sems med pa'i sems de yod dam (Venerable Subhuti, a thought which is no thought - does that thought exist?)

TT: nasun-a tegülder subuti yambar ali sedkil ügei tere sedkil buyu: (Venerable Subhuti, what is whithout thought - is that a thought?)

The question (tere sedkil buyu) is formulated ambiguously. The meaning of this question in Tibetan is clarified by the verb yod, which means to exist, to be present, but not to be something (a meaning which in the Tibetan language would be conveyed with the help of the verb yin). In Mongolian the choice of the verb does not allow to state this difference so clearly, and there are always two ways of translating the question: does that thought exist?, and is that a thought?.

Aryadeva (AD) gives a completely different rendering of this sentence: here an actor appears, represented by the pronoun ken (who), the verbal noun sedkigci (thinker), and the pronoun tegün (he, declined form of tere):

AD: subuti-a yambar sedkil ken ülü sedkigci tegün-tür sedkil büyükü (Subhuti! [Someone] who does not think any thought - does he have a thought?)

The pronoun ken originated from the erroneous interpretation of the Tibetan interrogative/relative pronoun gang, the range of meanings of which includes who. This, in turn, caused the interpretation of sems med pa (no thought) as an attribute to gang, hence ken ülü sedkigci (who does not think). Possibly, the Locative form tegün-tür is used here to render the possessive meaning of the Genetive case used in the Tibetan sentence (sems med pa'i). If so, the translator, instead of copying the Tibetan sentence word by word, rephrased it, adding the pronoun tere (tegün) that referred to the previously used pronoun ken.

All translation techniques, including verbatim translation, involve a high degree of interpretation. Differences in the grammar of the Tibetan and Mongolian languages are significant, and the target language cannot provide vocabulary and grammatical structures fully equivalent to the original. On the one hand, this lack of means to transfer the unity of form and content into the target language gives birth to the "unnatural", artificial language of the translated 
text. On the other hand, it outlines the translator's understanding. Primarily, it is manifested in the choice of grammatical forms, and verbal forms in particular. For example, the Tibetan word sems (thought) is rendered by Mongolian translators as sedkil (thought), sedkigci (thinker), sedkimüi (think), and sedkiküi (thinking) in the same fragment. Besides that, the translator's understanding is reflected in the interpretation of polysemantic words. For instance, some of the mistakes shown in the examples above are found in the works of several translators: interpreting the Tibetan brgal ba (argument) as a form of rgal ba (to cross) occurs in the translations by Jay-a Pandita and Pandita Darqan Bla ma; the Tibetan gang is erroneously translated into Mongolian as ken (who) by Äryadeva and bSam gtan Sengge.

Another mistake - the translation of the Tibetan phrase ci sems as what do you think? - occurs in the works of Jay-a Pandita and Pandita Darqan Bla ma. These mistakes speak of common translation methods, and describe these methods as mechanical. The nature of these errors consists in relying on the first meaning of a word rather than basing its interpretation on the context of the sentence.

In this article, I do not mean to assess the correctness of the Mongolian translations in rendering of the content of the sūtra. However, the inner logic of each translation is a relevant issue, being a factor of the integrity of the target text. The text of the sūtra contains many repetitions, and in the Tibetan text the recurrent segments are rendered very accurately, which allows the reader to follow the logic of the dialogue. None of the Mongolian translations render the text in the same strict manner: the repeating passages of text are never rendered in exactly the same way. Only in the translation by Altan Gerel Ubasi the analysed fragment is a coherent piece of text, all parts of which agree in meaning. In each of the other six translations there is at least one case of misinterpretation, which makes the logic of the dialogue fall apart. It is remarkable that these inconsistencies were not dealt with in the process of editing.

Although the analysed material is too specific to base generalisations on, it suggests that the tendency of following the Tibetan text word-for-word grew with time: the translations that are dated to the very beginnig of the seventeenth century can be described as more "liberal", unsettled in style, while the ones that come from the second half of the seventeenth century or later demonstrate a stronger Tibetan influence. This tendency reflects the growing role of the Tibetan stratum in the Mongolian Buddhist culture throughout the seventeenth century. The research shows that the development of the canonisation process, the forming of the literary repertoire, was well reflected in the styles of translation throughout the seventeenth century. 


\section{What is translated?}

The later translations, based on the technique of verbatim rendering of the source text with minimal interpretation, are a rather transparent object for investigation, and the most controversial at the same time. Above all this concerns the translation by Jay- $a$ Pandita, who implements the method of verbatim translation to the extreme. The characteristics of his style make it quite clear that the translator's goal was to most carefully preserve the wording of the sacred text - the buddhavacana. However, it is beyond debate that the target text is not intelligible, at least not without reference to the Tibetan original. What then was the purpose of this translation, and who was the addressee?

To answer this question one is bound to consider the translator's understanding of the text. Even mechanical translation cannot avoid interpretation, especially when the source and target languages are as different as Tibetan and Mongolian, and it is the translator's choices that reveal his understanding. The analysed fragment of the translation by Jay-a Pandita contains several cases of misinterpretation of the meaning of the original text, while the lack of conformity between the different parts of the dialogue describes his manner of translation as improvisational, as if the translator did not know a priori what sentence was to follow. ${ }^{40}$

The awkward picture suggested by these observations is hardly acceptable. It implies that the translator, who received his education in Tibet, ${ }^{41}$ did not understand the Tibetan text, was not familiar with the interpretation of its content, and that his translation did not undergo an editing process. This kind of description of the translation process would characterise it as a meaningless mechanical act, the purpose of which is purely symbolical and ritualistic. However, there is another way to explain this translation technique, based on the premise that it was a most meaningful act, and the translator pursued rather particular goals. Yet, what could these goals possibly be?

The fact that the target text does not make sense cannot be denied. This leaves only one possible explanation: it was not an issue. The translator did not search for the correct meaning in the Mongolian text, and the inconsistence of the text that he created (possibly, even his own misunderstanding) did not disturb him. Probably, it did not even exist for him, because he was concerned with something else.

40 The peculiarities of the translation style of Jay-a Pandita have been described before. See: TSENDINA 2001; Yakhontova 1986. It has been suggested that he employed a technique of oral translation, which involved Jay-a Pandita translating the Tibetan text aloud and a scribe writing his words down on a special board, for the text then to be corrected and re-written on paper. KARA 2005: 216-217.

41 Norbo 1999: 40-42. 
Supposing the text underwent editing, semantic disagreement was obviously not the object of the editor's attention either. This leaves the form, the wording of the scripture to be the only relevant matter in the translated process.

However, this is not to say that the translator himself saw things this way. On the contrary, according to the Buddhist doctrine, both form and meaning are to be guarded with equal care, and there is no doubt that Jay-a Pandita based his work on this principle. ${ }^{42}$ The meaning as seen by the translator must be found elsewhere, not in the target text as we see it. Obviously, the meaning of the scripture, inseparable from its form, is in the original text. For the Mongolian translator it is the Tibetan source.

Here the special role of the Tibetan language in Mongolian culture has to be taken into account. The translators, who received their education and studied the texts in Tibetan, were familiar with the whole discourse of Buddhism in this language. This means that for these translators buddhavacana probably was the Tibetan text in its integrity, and it was hardly possible to separate form and content that are deeply interconnected. That is to say that the technique of verbatim translation represents the attempt to transfer the unity of form and content of the sacred text from one language into another. As translation can never secure full equivalence, this technique compromises the quality of the translated text in terms of the target language. However, it does not compromise the translator's goal to preserve the integrity of buddhavacana. As long as the target language does not provide suitable means for that, a new language is created (besides peculiarities of grammar, it is also manifested in the vocabulary of the later translations, where phonetic borrowings from Tibetan start to appear). This artificial language seems to lack inner logic and rules, but its main, if not the only, purpose is to preserve the wholeness of the Word of the Buddha. This entirety of form and content, understood as the essence of buddhavacana, must be the canonicity, the sacred essence of the sūtra as seen by the Mongolian translator. ${ }^{43}$

42 The nuances of the form/meaning discourse in Buddhism are discussed in Lamotte 1985. In practice the balance of these concepts was dealt with in rather different ways, depending on the region. On the patterns of scripture acculturation and approaches to translation in different Buddhist cultures see Nattier 1990; Hartmann 2009.

43 The questions concerning the purposes of this kind of verbatim translation remain open. It could hardly be effectively used for studying the sütra, and the assumption that it was intended as a text for readers who were familiar with the Tibetan version brings the speculations about the possible practical purposes of such translation to naught. Keeping in mind the significance of devotional aspects in what concerns the motives for translation of sacred texts, it is possible that the purposes of translation could be purely extra-textual. It is not improbable that the translated text was intended to function as a ritual object, which could include ceremonial recitation, or worshipping of the text as the Word of the Buddha translated into the Mongolian language. 
Some of the features characteristic of verbatim translation are also found in the texts where different techniques are combined. However, the interpretation of the methods employed by the translators of these works is more challenging due to the mixed character of these techniques. The method of restructured verbatim translation, characteristic, in the first place, of the Anonymous translation, is similar to the strict method of Jay-a Pandita's work in many ways. However, those minimal alterations allowed in this technique make a significant difference: they reveal an intention of making the text understandable for a Mongolian reader, a respect for the rules of the target language, and, therefore, suggest that the purposes of this translation were partly practical. This suggests that the understanding of canonicity here is slightly different from the scheme described above. The translators do not perceive buddavacana as a fixed, invariable text that is to be transferred into the target language as an indivisible whole. The fidelity to the source text is manifest in cherishing its every word, but the careful interpretations of the ambiguous elements of text demonstrate a skillful technique, and an attempt to consciously render the meaning of each sentence.

The translation by Altan Gerel Ubasi stands out, demonstrating the most masterly and balanced handling of this method, implying that it is possible to transfer the qualities of buddhavacana into another language and find suitable equivalents to the words and structures of the original text. The above-mentioned passage from the colophon, in which Altan Gerel Ubasi claims to have studied multiple Tibetan texts, suggests that in some traditions the source text was not treated as an indisputable authority, but as a result of work of other translators that could be examined critically. In other words, it is possible that for Altan Gerel Ubasi the Tibetan text was not the immutable Word of the Buddha, but a translation, an interpretation of this Word. This allowed to compare different Tibetan sources in search of the correct understanding.

The techniques found in the earlier translations are a vague subject, primarily due to the problem of the missing source texts. As far as can be inferred from the Mongolian texts alone, all the earlier translations tend to neglect the exact wording of the Tibetan text and restructure the sentences in accordance with the translator's understanding. Moreover, it is now clear that a translator could use more than one source text, and what seems to be an interpretation of the Tibetan text may prove to be a result of collating several Tibetan sources.

Just like the verbatim translations, the ones based on the interpretational technique demonstrate a visible lack of consistency in content. If in the case of Jay-a Pandita it is plainly explained by the straightforward links to the grammar of the source text, here the reasons for tolerating the incoherence of content remain hidden. However, it could be of similar nature. What seems to be an 
inconsistency of the target text may, too, be the result of following the source text, which is harder to trace not only because of the absence of the source, but also because the technique of the earlier translators is less obvious (or, possibly, more complex). For instance, the work of the Three Translators demonstrates multiple examples of unconformity in translating terms, and the translation by Aryadeva contains numerous mistakes, some of which suggest that the translator's knowledge of the Tibetan language was poor (at the same time, such observations could not be made about the translations by bSam gtan Sengge and Pandita Darqan Bla ma). Common mistakes found in these translations also show that their methods were akin, while the wording of their texts demonstrates an endeavour to create a Mongolian text, not to copy the Tibetan original to a dot. It is possible that the differences between the earlier translations come not only from Tibetan sources, but also from the particular qualities of the interpretational approach. It appears safe to state that the earlier translators considered it appropriate to translate buddhavacana into their language, making it understandable to a Mongolian reader.

\section{Conclusion}

In this article, I suggested a preliminary model of the evolution of the manifestations of canonicity in Mongolian Buddhist text culture in the seventeenth century which is a model of the development of the literary repertoire in the domain of Buddhist scripture translation. The cornerstone of this model is the concept of source text. In the early stages of the canonisation process, the source text appears to be treated as a medium, a means of carrying buddhavacana, hence the possibilities of critical and interpretational approaches to scripture translation. Combined with the absence of a general line that governs the production of Buddhist texts in the Mongolian language, this understanding of canonicity manifested itself in the emergence of a variety of translations. The absence of an inalterable bond between a text's form and its sacred content describes the earlier concept of canonicity in translation as a dynamic process: a search for the ultimate form to render the text's meaning, a form to hold the Word of the Buddha. This search for canonicity resulted in equaling the source text to buddhavacana. The canon of the Mongolian translations of late seventeenth-early eighteenth centuries is the Tibetan source text. The model suggested in this article can be used as a tool to study translations of Buddhist scriptures in Mongolia. Beyond doubt, a study of a wider range of textual material will shed light on new facets of this topic. 


\section{Abbreviations}

IOM RAS: Institute of Oriental Manuscripts, Russian Academy of Sciences, St. Petersburg

Text sources (Tibetan and Mongolian Manuscript and Blockptint Editions of the Aștasāhasrikā)

sDe dge Brgyad stong bzhugs so. Xyl., TBRC < http://tbrc.org/\#!rid=W30532>; (last accessed 26.10.2014), sDe dge par phud bKa' 'gyur vol. 33, $286 \mathrm{ff}$.

ADMs Naiman mingran silüg-tü kemekü jaddamba bolui. Ms., Museum of Ts. Damdinsuren, Ulan-Bator, XT-7, 286 ff. Aștasāhasrikā transl. by Aryadeva

A-Kangxi Qutur-tu bilig-ün cinadu kürügsen naiman mingr-a-tu. Xyl., reprinted in Lokesh Chandra (Ed.), Mongolian Kanjur, vol. 46 (New Delhi: International Academy of Indian Culture, 1977), Aștasāhasrikā, anonymous transl.

JPMs Qutur-tu bilig-ün cinadu kürügsen naiman mingra-tu. Ms., IOM RAS, Q1, 388 ff. Așțasāhasrikā transl. by Jay-a Paṇdita

PDLMs Qutuү-tu bilig-ün cinadu kijayar-a kürügsen naiman mingyan. Ms., IOM RAS, Q223, $237 \mathrm{ff}$. Aștasāhasrikā transl. by Paṇdita Darqan Bla ma

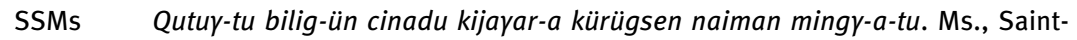
Petersburg University, Mongolian bKa' 'gyur vol. 45, 83 ff. Așțasāhasrikā transl. by bSam gtan Sengge

TTMsVol1 Qutuy-tu bilig-ün cinadu kijayar-a kürügsen naiman mingran. Ms., Royal Library, Copenhagen, MONG. 481, 158 ff. Așțasāhasrikā transl. by Diduyba dKa' bcu Bla ma, Durqar Omboo Sñagbo Baysi, Brasi Baysi

TTMsVol2 Qutur-tu sayitur medekü-yin cinadu kijayar-a kürügsen naiman mingyan. Ms., Royal Library, Copenhagen, MONG. 482., 159 ff. Așțasāhasrikā transl. by Diduyba dKa' bcu bla ma, Durqar Omboo Sñagbo Baysi, Brasi Baysi

AGMs 'Phags pa shes rab kyi pha rol tu phyin pa brgyad stong pa bzhugs so. Qutur-tu bilig-ün cinadu kijayar-a kürügsen naiman mingyan neretü. Ms., private collection, 209(?) ff. Aștasāhasrikā transl. by Altan Gerel Ubasi

TPMs [Title not available] Ms., photocopy of a fragment of a manuscript from a private collection, ff. 1-3, 314-318. Așțasāhasrikā transl. by Thar pa Paṇ̦ita

\section{References}

Alekseev, Kirill / Turanskaya, Anna (2013): “An Overview of the Altan Kanjur Kept at the Library of the Academy of Social Sciences of Inner Mongolia”. Asiatische Studien/Études Asiatiques 67.3: 755-782.

Bawden, Charles / Heissig, Walther (1971): Catalogue of Mongol Books, Manuscripts and Xylographs. Copenhagen: The Royal Library.

Bilguudey, G. (1998): Ts. Damdinsurengiyn ger muzeyn mongol nomyn burtgel. Vol. I. Ulaanbaatar. Catalogue of Ancient Mongolian Books and Documents of China (1999): Vol. 1. Beijing: Beijing Library Press.

Conze, Edward (1975): The Perfection of Wisdom in Eight Thousand Lines \& It's Verse Summary. Bolinas, California: Four Seasons Foundation.

Damdinsuren, Ts. (1987): Mongolyn uran zokhiolyn ov ulamzhlalyn asuudald I. Ulaanbaatar: SUA-iin hevlel. 
Even-Zohar, Itamar (1990): “Polysystem Studies”. Poetics Today, International Journal for Theory and Analysis of Literature and Communication 11.1.

Dashbadrakh, D. (2004): Mongolyn khutagtuudyn namtryn oillogo: XVII-XX zuun. Shinzhlekh ukhaan Akademi: Tuukhiyn Khureelen.

Hartmann, Jens-Uwe (2009): "From words to books: Indian Buddhist manuscripts in the first millennium CE”. In: Buddhist Manuscript Cultures. Edited by S.C. Berkwitz, J. Schober, C. Brown. Abingdon: Routledge, 95-105.

Heissig, Walther (1957): "Zur Entstehungsgeschichte der Mongolischen Kandjur-Redaktion der Ligdan Khan-Zeit (1628-1629)”. In: Studia Altaica. Festschrift für Nikolaus Poppe zum 60. Geburtstag am 8. August 1957. Wiesbaden: Harrassowitz, 71-87.

Heissig, Walther (1962): Beiträge zur Übersetzungsgeschichte des mongolischen buddhistischen Kanons. Abhandlungen der Akademie der Wissenschaften in Göttingen. Philologisch-historische Klasse, Dritte Folge, Nr. 50. Göttingen: Vandenhoeck \& Ruprecht.

Jones, Lindsay (ed.) (2005): Encyclopedia of Religion. Second Edition. Vol. 3. Macmillan Reference USA, Thomson Gale.

Kara, György (2005): Books of the Mongolian Nomads. More than Eight Centuries of Writing Mongolian. First English edition translated from the Russian by John R. Krueger. Indiana University Bloomington: Research Institute for Inner Asian Studies.

Kas'yanenko, Zoya (1993): Katalog peterburgskogo rukopisnogo "Gandzhura”. Moskva: Nauka. Kämpfe, Hans-Rainer (1983): Das Asarayči neretü -yin teüke des Byamba erke daičing alias Šamba jasay (Eine mongolische Chronik des 17. Jahrhunderts). Wiesbaden: Otto Harrasowitz.

Kollmar-Paulenz, Karénina (2001): Erdeni tunumal neretü sudur: die Biographie des Altan qayan der Tümed-Mongolen: ein Beitrag zur Geschichte der religionspolitischen Beziehungen zwischen der Mongolei und Tibet im ausgehenden 16. Jahrhundert. Wiesbaden: Harrassowitz.

Kollmar-Paulenz, Karénina (2002): “The Transmission of the Mongolian Kanjur: A preliminary Report”. In: The Many Canons of Tibetan Buddhism, PIATS 2000: Tibetan Studies: Proceedings of the Ninth Seminar of the International Association for Tibetan Studies. Edited by H. Eimer, D. Germano. Leiden: Brill, 151-176.

Lamotte, Étienne (1985): “The Assessment of Textual Interpretation in Buddhism”. Buddhist Studies Review 2.1; Reprinted in: Buddhist Hermeneutics. Edited by Donald S. Lopez Jr. Honolulu: Kuroda Institute Studies in East Asian Buddhism 6. 1992, 11-28.

Ligeti, Lajos (1942): Catalogue du Kanjur mongol imprimé. Budapest: Société Kőrösi Csoma.

Lokesh Chandra (ed.) (1977): Mongolian Kanjur. Vol. 46. Satapitaka series. New Delhi: International Academy of Indian Culture.

Long, Lynne (2010): “Medieval literature through the lens of translation studies. Bridging the interpretive gap". Translation Studies. Edited by Kate Sturge, Michaela Wolf 3.1: 61-77.

Lopez Jr., Donald S. (1995): “Authority and Orality in the Mahāyāna”. In: Numen 42: 21-47.

Lotman, Yuriy (1992): “Kanonicheskoe iskusstvo kak informatsionnyy paradoks”. In: Izbrannye stat'i. Vol. 1. Tallin: Alexandra, 243-247.

Nattier, Jan (1990): “Church Language and Vernacular Language in Central Asian Buddhism”. Numen 37: 195-219.

Norbo, Sh. (1999): Zaya-pandita (materialy k biografii). Elista: Kalmytskoe knizhnoe izdatelstvo.

Poppe, Nicholas et al. (1964): Catalogue of the Manchu-Mongol Section of the Toyo Bunko. Tokyo and Seattle: The Toyo Bunko \& the University of Washington Press. 
Reiss, Katharina / Vermeer, Hans J. (1984): Grundlegung einer allgemeinen Translationstheorie. Tübingen: Niemeyer.

Riftin, Boris (1974): “Tipologiya i vzaymosvyaz' srednevekovykh literatur”. In: Tipologiya $i$ vzaymosvyaz’ srednevekovykh literatur Vostoka i Zapada. Edited by B.L. Riftin et al. Nauka: Moscow, 9-116.

Sárközi, Alice (2010) “Translating the Buddhist Scriptures”. In: Mongolian Studies in Europe: Proceedings of the Conference held in November 24-25, 2008 in Budapest. Edited by Birtalan Agnes. Budapest: Eötvös Loránd University, Department of Inner Asian Studies, 101-109.

Sazykin, Aleksey (2001): Katalog mongol'skikh rukopisey i ksilografov Instituta vostokovedeniya Rossiyskoy Akademii nauk. Vol II. Moskva: Vostochnaya literatura RAN.

Skilling, Peter (1997): “From bKa' bstan bcos to bKa' 'gyur and bStan 'gyur”. In: Transmission of the Tibetan Canon. Papers Presented at a Panel of the $7^{\text {th }}$ Seminar of the IATS, Graz 1995, (Proceedings of the $7^{\text {th }}$ Seminar of the IATS, Graz 1995). (Beiträge zur Kultur- und Geistesgeschichte Asiens 22). Edited by Helmut Eimer. Österreichische Akademie der Wissenschaften. Philosophisch-Historische Klasse. Denkschriften, 257. Bd. Vienna, 87-111.

Smith, Wilfred Cantwell (1993): What is Scripture? A comparative Approach. London.

Tsendina, Anna (2001): “Dva mongol'skikh perevoda tibetskogo sochineniya 'Kniga syna”.

Mongolica 5. Edited by S.G. Klyashtornyy. St. Petersburg: Peterburgskoe vostokovedenie, 54-74.

Tuyay-a, Ü. (2008): Mongyol-un erten-ü nom bicig-ün teüke. Kökeqota: Öbör mongyol-un arad-un keblel-ün qoriy-a.

Uspensky, Vladimir (1997): "The Tibetan Equivalents to the Titles of the Texts in the St. Petersburg Manuscript of Mongolian Kanjur: A Reconstructed Catalogue”. In: Transmission of the Tibetan Canon. Papers Presented at a Panel of the 7th Seminar of the International Association for Tibetan Studies, Graz 1995. Edited by Helmut Eimer. Wien: Verlag der Österreichischen Akademie der Wissenschaften, 113-176.

Vermeer, Hans (2004): “Skopos and commission in translational action”. In: The Translation Studies Reader. Edited by Lawrence Venuti. London: Routledge, 221-232.

Vladimirtsov, Boris (2003): “Mongolskiy sbornik rasskazov iz Pañcatantra”. In: Raboty po literature mongol'skikh narodov. Edited by V.M. Alpatov et al. Moscow: Vostochnaya literatura, 77-204.

Yakhontova, Natalia (1986): "Vliyanie tibetskogo yazika na sintaksis oiratskikh perevodov". In: Mongolica pamyati Borisa Yakovlevicha Vladimirtsova (1884-1931). Edited by A.N. Kononov et al. Nauka: Moscow, 113-117.

Yampolskaya, Natalia (2013): Canonicity in Translation. Eight Mongolian Versions of the Aștasāhasrikā Prajñāpāramitā Sūtra. Dissertation submitted to the Faculty of Humanities at the University of Bern to obtain the degree of Doctor of Philosophy. Bern.

Self-publication. 